\title{
ブロッコリーの収穫後の呼吸特性と酸素透過度を 変えたフイルムによる鮮度保持効果
}

\author{
永井耕介* $*$ 小河拓也* ${ }^{*}$ 福嶋 昭* ・ 中川勝也*
}

\section{Characteristics of Respiration Rate in Harvested Broccoli and Effect of Packaging with Films of Different $\mathrm{O}_{2}$ Permeability on quality maintenance}

\author{
NAGAi Kousuke*, OgaWA Takuya*, FuKushima Akira* and NAKAgaWA Katsuya* \\ * Hyogo Prefectural Hokubu Agricultural Institute \\ Yasui, Wadayama-cho, Asako-gun, Hyogo, 669-52 Japan
}

\begin{abstract}
Respiration rate and ethylene $\left(\mathrm{C}_{2} \mathrm{H}_{4}\right)$ production in harvested broccoli (Brassica oleracea L.) were examined. Effect of packaging with films of different $\mathrm{O}_{2}$ permeability on quality maintenance was studied. (1) The higher the storage-temperature, the higher the respiration rate was observed. Seven days after harvest, the respiration rate decreased under $50 \%$ of that at the time of harvest. The production of $\mathrm{C}_{2} \mathrm{H}_{4}$ was slightly under $10^{\circ} \mathrm{C}$ and increased remarkably over $10^{\circ} \mathrm{C}$. (2) At the stage that the flower buds of broccoli became soft, the respiration rate increased. However, the effect of the stage of broccoli on respiration rate was less than on $\mathrm{C}_{2} \mathrm{H}_{4}$ production, $\mathrm{C}_{2} \mathrm{H}_{4}$ production increased remarkably at the stage that the flower buds became slightly soft. (3) The respiration rate of early cultivars were higher than that of medium and late cultivars. (4) The difference of effect among films on maintaining freshness was slightly at $0{ }^{\circ} \mathrm{C}$ and $5^{\circ} \mathrm{C}$ storages, a high fresh score was maintaind for 2 weeks at $0^{\circ} \mathrm{C}$ and 1 week at $5^{\circ} \mathrm{C}$ in almost all films. (5) At $10^{\circ} \mathrm{C}$ storage, a high fresh score was maintained for 4 days in almost all films. And a high fresh score was maintaind for 7 days in films with low gas permeability. At $20^{\circ} \mathrm{C}$ storage, a high fresh score was maintained for 4 days in films with low gas permeability. However, in films with low gas permeability an unfavorable off-flavor occurred. (6) These results indicate that at $10^{\circ} \mathrm{C}$ storage, quality is high in films with $\mathrm{O}_{2}$ permeability of about $4000 \mathrm{~m} \ell / \mathrm{m}^{2} \cdot \operatorname{day} \cdot \operatorname{atm}\left(15^{\circ} \mathrm{C}\right)$. However, it is suggested that the use of films with $\mathrm{O}_{2}$ permeability of over $10000 \mathrm{~m} \ell / \mathrm{m}^{2} \cdot$ day $\cdot \mathrm{atm}$ $\left(15^{\circ} \mathrm{C}\right)$ is practical, when the temperature of broccoli is over $20^{\circ} \mathrm{C}$.
\end{abstract}

(Received Jun. 18, 1997)

今日の消費者は野菜に「美味しさ」や「栄養価」のみ ならず，「新鮮さ」を強く求めている1)。

ブロッコリー（Brassica oleracea L.）は，流通途上 で黄化や花蕾が開花するなどして，品質低下を生じやす
(22),3)。一般に低温ほど品質保持期間が長い4)ことから， 高温時には予冷・保冷等の低温流通が行われている。し かし，実際の流通段階では品温変化があり ${ }^{5), 6) ， そ の た ~}$ めに，品質低下を起こす場合も少なくない。また，鮮度 
Table 1 The characteristics of films used

\begin{tabular}{|c|c|c|c|c|c|}
\hline & film & $\begin{array}{l}\mathrm{O}_{2} \text { permeability } * 1 \\
\mathrm{~m} \ell / \mathrm{m}^{2} \cdot \text { day } \cdot \text { atm }\end{array}$ & $\begin{array}{l}\text { size } \\
\mathrm{mm}\end{array}$ & $\begin{array}{c}\text { thickness } \\
\qquad \mu \mathrm{m}\end{array}$ & $\begin{array}{l}\text { material*2 } \\
\text { of film }\end{array}$ \\
\hline L 1 & & 7,000 & $438 \times 306$ & 16.4 & LDPE \\
\hline $\mathrm{L} 2$ & & 5,400 & $438 \times 306$ & 20.3 & LDPE \\
\hline L 3 & & 4,100 & $438 \times 306$ & 27.8 & LDPE \\
\hline $\mathrm{L}_{4}$ & & 1,900 & $438 \times 306$ & 38.4 & LDPE \\
\hline H 1 & $($ microhole $) * 3$ & 100,000 & $431 \times 279$ & 40.6 & $\mathrm{OPP}$ \\
\hline $\mathrm{H} 2$ & (microhole) & 28,000 & $431 \times 280$ & 40.4 & OPP \\
\hline H 3 & (microhole) & 10,000 & $433 \times 278$ & 40.5 & OPP \\
\hline H 4 & (microhole) & 4,000 & $432 \times 282$ & 39.6 & OPP \\
\hline
\end{tabular}

*1 measured at $15^{\circ} \mathrm{C}$

*2 LDPE : low density polyethylene, OPP : polypropylen

*3 microhole film treated with laser beams

保持の観点から包材の機能性も検討されている77,8)。機 能性フィルムについては近年, レーザー光による微細孔 フィルムなど新たなフィルムが開発されている。しかし ながら，その効果的な利用法が確立されていない。

そこで，ブロッコリーの収穫後の呼吸特性を調べると ともに, 酸素透過量を変えたフィルムの鮮度保持効果を 検討した。

\section{実験材料および方法}

\section{1. 実験 材料}

実験に供したブロッコリーは兵庫県立中央農業技術セ ンター（1994年加西市）と同北部農業技術センター （1995年和田山町）で栽培したものを用いた。1994年 は12月10日と 20 日に収穫した試料を，1995年は10月 13 日と10月18日に収穫した試料を用いた。

栽培種は，1994年が唐嶺”緑嶺”グリンビューティ”八 イツ’を，1995年は“ハイツを用いた。ブロッコリーの重 量は250〜280gのものを用いた。

\section{2. 実験方法}

試験 1 ブロッコリーの収穫後の呼吸およびエチレン発

\section{生量}

(1) 花蕾の生育ステージ：花蕾の生育ステージ別呼吸 特性およびエチレン発生量を把握するため, 花蕾の状況 が緑色で硬い, 緑色で少し軟らかい, 緑色で軟らかい, 黄化始期で軟らかいの 4 段階の試料を用いた。生育ステ 一ジに関する調査の供試品種は‘唐嶺’とした。

(2) 保存方法：収穫後の保存温度は $0,5,10,15$ と $20^{\circ} \mathrm{C}$ の 5 区とした。保存の包装はOPP微細孔フィル 么袋 (酸素透過量： $20,000 \mathrm{~m} \ell / \mathrm{m}^{2} \cdot$ day $\cdot \mathrm{atm}, 15^{\circ} \mathrm{C}$, 大きさ： $197 \times 370 \mathrm{~mm}$ ，厚さ： $25 \mu \mathrm{m}$ ）に入れ保存は立ち 姿で行った。

(3) 呼吸量, エチレン発生量およびフィルム内のガス
濃度の測定：呼吸量，エチレン発生量の測定に用いた試 料はガラス製デシケー夕内に保ち, 試料取り出し用のデ シケータのふたの部分はラバーストッパーで固定した。 二酸化炭素（以下 $\mathrm{CO}_{2}$ と略す）およびエチレンの濃度は 密封直後と密封 2 時間後に測定した。

$\mathrm{CO}_{2}$ 濃度は収穫直後, 保存試験開始 2 日後および 7 日 後に測定した。収穫直後の測定は保存設定温度に 4 時間 放置後測定を開始した。

$\mathrm{CO}_{2}$ 濃度は侏住友ペークライト製ガスアナライザー （モデルMAP-T3000）で測定し，エチレン濃度は侏) 日立製作所製ガスクロマトグラフ（モデル163型，検知 器 FID ) で測定した。

\section{試験 2 酸素透過量を変えたフィルムの鮮度保持効果}

(1) 機能性フィルムと保存温度：供試したフィルム包 材の種類と特性はTable 1 に示した。保存温度は $0{ }^{\circ} \mathrm{C}$, $5{ }^{\circ} \mathrm{C}, 10^{\circ} \mathrm{C}$ と $20^{\circ} \mathrm{C}$ の 4 区とした。保存施設は日本医化 器製作所製のインキュベータ（BIOTRON LPH200 型）を使用した。

(2) 袋内のガス組成：5 ${ }^{\circ} \mathrm{C}, 20^{\circ} \mathrm{C}$ 保存における 1 日, 4 日，7 日後の袋内の $\mathrm{CO}_{2}$ ，酸素（以下 $\mathrm{O}_{2}$ と略す）濃 度を測定した。測定には試験 1 と同様の装置を用いた。

(3) 官能評価：鮮度スコア等の評価は 5 人のパネリス トを用い，各パネリストが 5 から 1 の 5 段階で評価を行 つた。

鮮度スコアは以下のとおりとした。

5 : 収穫直後の状態

4：商品性は高いが，若干しおれ等がみられる

3 ：商品性はあるが，かなり鮮度低下している。

2 ：商品性はかなり低下している（商品性の限界）

1 ：食べられない

花蕾の色スコアは以下の通りとした。

5：緑色 4：緑色～薄緑 3：薄緑 2：黄緑 1： 
黄色

開封時の品質調査では異臭発生やかび等の外観調査を 行った。

\section{実 験 結 果}

\section{試験 1 ブロッコリーの収穫後の呼吸およびエチレン発 生量}

Table 2 に収穫後の保存温度とブロッコリーの呼吸量 並びにエチレン発生量の関係を示した。 $\mathrm{CO}_{2}$ 発生量およ びエチレン発生量は保存温度が高いほど増加しており, $\mathrm{CO}_{2}$ 発生量は $5{ }^{\circ} \mathrm{C}$ 基準にみると $10^{\circ} \mathrm{C}, 15^{\circ} \mathrm{C}, 20^{\circ} \mathrm{C}$ は $5{ }^{\circ} \mathrm{C}$ のそれぞれ約1.5倍， 3 倍，4.3倍であった。 $0{ }^{\circ} \mathrm{C}$ $5{ }^{\circ} \mathrm{C}$ の約 $1 / 2$ 量であった。エチレン発生量は $10^{\circ} \mathrm{C}$ 以下で は比較的少なく， $15^{\circ} \mathrm{C}$ 以上で激增していた。

Table 3 にブロッコリーの花蕾の成育ステージと呼吸 量並じにエチレン発生量の関係を示した。呼吸量は花蕾 の状況による差が小さいが，花蕾が軟らかい段階IIIで最 も多い傾向にあった。エチレン発生量は花蕾が硬い段階 I では比較的少なく，花蕾が少し軟らかくなった段階II で増加しはじめ，花蕾が軟らかい段階IIIで急増した。そ の後，花蕾が黄化しはじめる段階IVではエチレン発生量 は減少した。

Table 4 にブロッコリーの品種別呼吸性を示した。供 試 4 品種の中で差がみられ，ハイツ’の $\mathrm{CO}_{2}$ 排出量が最 も多かった。収穫直後および 2 日後でば緑嶺’の排出量 が少ない傾向にあった。 $\mathrm{CO}_{2}$ 排出量は収穫後减少傾向に あり，収穫 7 日後ではほぼ半量以下に減少していた。

\section{試験 $2 \mathrm{O}_{2}$ 透過量を変えたフィルムの鮮度保持効果}

Table 5 には $0{ }^{\circ} \mathrm{C}, 5{ }^{\circ} \mathrm{C}$ の保存温度条件に㧍ける各種 フィルムの鮮度保持効果を示した。外観鮮度スコア 4.0 以上を高鮮度状態とした。 $0{ }^{\circ} \mathrm{C}$ の保存条件下では無包装 を除きほぼ全ての包材で 2 週間程度高鮮度状態に保てた。 保存 7 日後の調查では全ての包材で色調の変化および異 臭の発生はみられなかった。 $5{ }^{\circ} \mathrm{C}$ の保存条件下では無包 装を除きほぼ全ての包材で7日間高鮮度状態に保てた。 保存 7 日後の調査ではL 1 とH 1 の包材で色調がやや薄 緑のものがみられたが，他の包材では色調変化はみられ なかった。異臭の発生はL 4 と H 4 の包材で少しみられ た。

Table 6 には $10^{\circ} \mathrm{C}, 20^{\circ} \mathrm{C}$ の保存温度条件における各 種フィルムの鮮度保持効果を示した。 $10^{\circ} \mathrm{C} の$ 保存条件 下では無包装とL 2 の包材を除きほぼ全ての包材で 4 日 間高鮮度状態に保てた。保存 7 日後でも L $3, \mathrm{~L} 4$ およ びH 4 の包材では高鮮度状態に保てた。7 日後の色調変 化では緑色に保てたのはL 3，L 4，H 3 およびH 4 の
Table 2 Effect of storage temperature of broccoli 'Tourei' on respiration rate and $\mathrm{C}_{2} \mathrm{H}_{4}$ production

\begin{tabular}{ccc}
\hline $\begin{array}{c}\text { temperature } \\
\text { of storage } \\
\left({ }^{\circ} \mathrm{C}\right)\end{array}$ & $\begin{array}{c}\text { respiration } \\
\text { rate } \\
\left(\mathrm{CO}_{2} \mathrm{mg} / \mathrm{kg} / \mathrm{hr}\right)\end{array}$ & $\begin{array}{c}\mathrm{C}_{2} \mathrm{H}_{4} \\
(\mu \mathrm{l} / \mathrm{kg} / \mathrm{hr})\end{array}$ \\
\hline 0 & 58 & 0.1 \\
5 & 95 & 0.1 \\
10 & 145 & 0.6 \\
15 & 289 & 2.5 \\
20 & 414 & 5.1 \\
\hline
\end{tabular}

stage of the flower buds of broccoli : hard little soft

Table 3 Effect of stage of broccoli 'Tourei' on respiration rate and $\mathrm{C}_{2} \mathrm{H}_{4}$ production

\begin{tabular}{ccc}
\hline $\begin{array}{c}\text { stage* } \\
\text { broccli }\end{array}$ & $\begin{array}{c}\text { respiration } \\
\text { rate } \\
(\mathrm{CO} 2 \mathrm{mg} / \mathrm{kg} / \mathrm{hr})\end{array}$ & $\begin{array}{c}\mathrm{C}_{2} \mathrm{H}_{4} \\
(\mu \ell / \mathrm{kg} / \mathrm{hr})\end{array}$ \\
\hline I & 278 & 2.8 \\
II & 276 & 7.0 \\
III & 318 & 14.1 \\
IV & 254 & 6.8 \\
\hline
\end{tabular}

storage temperature : $15^{\circ} \mathrm{C}$

* stage of the flower buds of broccoli;

I : green and hard, II. : green and little soft,

III : green and soft, IV : yellow and soft

Table 4 Respiration rate of several cultivars of broccoli

\begin{tabular}{lccc}
\hline \multirow{2}{*}{ cultivar } & \multicolumn{3}{c}{ respiration rate*1 $\left(\mathrm{CO}_{2} \mathrm{mg} / \mathrm{kg} / \mathrm{hr}\right)$} \\
\cline { 2 - 4 } & \multicolumn{3}{c}{ storage period $($ days) } \\
\cline { 2 - 4 } & $\mathrm{O}^{* 2}$ & 2 & 7 \\
\hline Ryokurei & 282 & 250 & 147 \\
Tourei & 312 & 273 & 140 \\
Greenbyutyi & 347 & 336 & 157 \\
Haitsu & 378 & 366 & 169 \\
\hline
\end{tabular}

stage of the flower buds of broccoli : green and hard $\sim$ green and little soft

* 1: storage temperature : $15^{\circ} \mathrm{C}$

* 2: 0 day : measured after 4 hours storage at $15^{\circ} \mathrm{C}$

4 種類の包材であった。異臭の発生はL 2，L $3 ， \mathrm{H} 3$ では少し，L4，H4ではかなり感じられた。

$20^{\circ} \mathrm{C}$ の保存条件下ではL $3, \mathrm{~L} 4, \mathrm{H} 4$ の 3 包材で 4 日間比較的高鮮度の状態に保てた。色調では $\mathrm{H} 4$ の包材 が緑色を保持した。異臭の発生は H 1 の包材ではみられ ず，L 3，L 4，H 3，H 4 の包材ではかなり感じられ た。 
Table 5 Effect of plastic films on maintaining freshness of broccoli 'Haitsu' at $0^{\circ} \mathrm{C}$ and $5{ }^{\circ} \mathrm{C}$ storage

\begin{tabular}{|c|c|c|c|c|c|c|c|c|c|c|c|c|}
\hline \multirow{4}{*}{ film*1 } & \multicolumn{6}{|c|}{$0^{\circ} \mathrm{C}$ storage } & \multicolumn{6}{|c|}{$5^{\circ} \mathrm{C}$ storage } \\
\hline & \multicolumn{3}{|c|}{ fresh score $* 2$} & color $* 3$ & stench $^{* 4}$ & \multirow{3}{*}{$\begin{array}{l}\text { weight } \\
\text { decrease } \\
\text { per day }\end{array}$} & \multicolumn{2}{|c|}{ fresh score } & & \multirow{2}{*}{\multicolumn{2}{|c|}{$\frac{\text { color }}{\text { (days) }}$}} & \multirow{3}{*}{$\begin{array}{c}\text { weight } \\
\text { decrease } \\
\text { per day } \\
\left(10^{-2} \%\right)\end{array}$} \\
\hline & \multicolumn{5}{|c|}{ storage period (days) } & & \multicolumn{3}{|c|}{ storage period (days) } & & & \\
\hline & 4 & 7 & 14 & 7 & 7 & & 4 & 7 & 14 & 7 & 7 & \\
\hline L 1 & 5.0 & 4.8 & 4.5 & 5 & 1 & 35 & 4.2 & 4.0 & 2.3 & 4 & 1 & 74 \\
\hline L 2 & 5.0 & 4.8 & 4.2 & 5 & 1 & 29 & 4.0 & 4.0 & 1.3 & 5 & 1 & 91 \\
\hline L 3 & 5.0 & 4.8 & 4.2 & 5 & 1 & 26 & 4.5 & 4.5 & 1.0 & 5 & 1 & 102 \\
\hline L 4 & 5.0 & 4.8 & 4.5 & 5 & 1 & 24 & 5.0 & 5.0 & 2.0 & 5 & 1 & 61 \\
\hline $\mathrm{H} 1$ & 5.0 & 4.8 & 4.2 & 5 & 1 & 41 & 4.5 & 4.0 & 1.1 & 4 & 1 & 63 \\
\hline H 2 & 5.0 & 4.8 & 4.0 & 5 & 1 & 24 & 5.0 & 4.5 & 1.2 & 5 & 1 & 76 \\
\hline H 3 & 5.0 & 4.8 & 3.5 & 5 & 1 & 23 & 5.0 & 4.0 & 1.7 & 5 & 1 & 84 \\
\hline $\mathrm{H} 4$ & 5.0 & 4.8 & 4.5 & 5 & 1 & 18 & 5.0 & 4.3 & 2.2 & 5 & 1 & 46 \\
\hline non-pack & 3.0 & 2.5 & 1.0 & 5 & 1 & 162 & 2.0 & 1.0 & 1.0 & 3 & 1 & 326 \\
\hline
\end{tabular}

*1 film : same as in Table 1

* 2 fresh score ; 5 : Excellent 1 : not edible

*3 color score ; 5 : Green $\sim 1$ : yellow

*4 stench score ; $3:$ terrible, $2:$ small, $1:$ non

Table 6 Effect of plastic films on maintaining freshness of broccoli 'Haitsu' at $10^{\circ} \mathrm{C}$ and $20^{\circ} \mathrm{C}$ storage

\begin{tabular}{|c|c|c|c|c|c|c|c|c|c|c|c|c|}
\hline \multirow{4}{*}{ film*1 } & \multicolumn{6}{|c|}{$10^{\circ} \mathrm{C}$ storage } & \multicolumn{6}{|c|}{$20^{\circ} \mathrm{C}$ storage } \\
\hline & \multicolumn{3}{|c|}{ fresh score*2 } & \multirow{2}{*}{\multicolumn{2}{|c|}{$\frac{\text { color }^{* 3} \text { stench } * 4}{(\text { days })}$}} & \multirow{3}{*}{$\begin{array}{l}\text { weight } \\
\text { decrease } \\
\text { per day } \\
\left(10^{-2} \%\right)\end{array}$} & \multicolumn{3}{|c|}{ fresh score } & \multirow{2}{*}{\multicolumn{2}{|c|}{$\frac{\text { color }}{\text { (days) }}$}} & \multirow{3}{*}{$\begin{array}{r}\text { weight } \\
\text { decrease } \\
\text { per day } \\
\left(10^{-2} \%\right)\end{array}$} \\
\hline & \multicolumn{3}{|c|}{ storage period (days) } & & & & \multicolumn{3}{|c|}{ storage period (days) } & & & \\
\hline & 4 & 7 & 14 & 7 & 7 & & 4 & 7 & 14 & 7 & 7 & \\
\hline L 1 & 4.0 & 3.5 & 1.0 & 4 & 1 & 135 & 3.5 & 1.0 & - & 1.5 & 2 & 168 \\
\hline L 2 & 3.5 & 3.0 & 1.0 & 4 & 2 & 80 & 3.8 & 1.0 & - & 2 & 2 & 220 \\
\hline L 3 & 4.5 & 4.3 & 1.0 & 5 & 2 & 66 & 4.3 & 2.0 & - & 4 & 3 & 106 \\
\hline L 4 & 4.0 & 4.0 & 1.0 & 5 & 3 & 53 & 4.0 & 2.5 & - & 4 & 3 & 82 \\
\hline $\mathrm{H} 1$ & 4.0 & 3.8 & 1.0 & 4 & 1 & 94 & 1.3 & 1.2 & - & 2 & 1 & 199 \\
\hline $\mathrm{H} 2$ & 4.0 & 3.8 & 1.0 & 4 & 1 & 47 & 2.5 & 1.0 & - & 2 & 2 & 126 \\
\hline H 3 & 4.0 & 3.8 & 1.0 & 5 & 2 & 49 & 3.5 & 1.0 & - & 4 & 3 & 80 \\
\hline H 4 & 4.5 & 4.3 & 1.2 & 5 & 3 & 37 & 4.3 & 2.5 & - & 5 & 3 & 58 \\
\hline non-pack & 2.7 & 1.0 & $-* 5$ & 2 & 1 & 456 & 1.0 & 1.0 & - & 2 & 1 & 678 \\
\hline
\end{tabular}

$* 1$ film; same as in Table 1

$* 2 \sim * 4$; same as in Table 5

*5 - ; sample rotted

1 日当たりの重量減はフィルムにより異なっており，

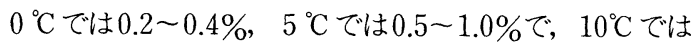
$0.4 \sim 1.4 \%, 20^{\circ} \mathrm{C}$ では0.6 2.2\%となっており，保存温 度が高いほど $\mathrm{O}_{2}$ 透過性の違いによる重量減の差が大き くなる傾向にあった。 $\mathrm{O}_{2}$ 透過性の低いフィルムほど重 量減は少ない傾向にあった（Table 5，6）。

保存中の供試フィルム内の $\mathrm{CO}_{2}$ 濃度をTable 7 に示し た。 $5{ }^{\circ} \mathrm{C}$ の保存条件下では $\mathrm{O}_{2}$ 透過性の低い包材ほど $\mathrm{CO}_{2}$ 濃度が高くなっており，L4のフィルムでは保存 1 日後

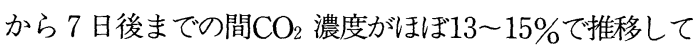
いた。また，H 4 フィルムは10１8\%で推移しており，
保存日数に伴い増加傾向にあった。

$20^{\circ} \mathrm{C}$ 保存条件下での供試フィルム内 $\mathrm{CO}_{2}$ 濃度も $\mathrm{O}_{2}$ 透 過性の低い包材ほど高くなっており， $5{ }^{\circ} \mathrm{C}$ 保存に比べて フィルム内の $\mathrm{CO}_{2}$ 濃度は全体に高かった。L4のフィル ムでは保存 1 日後から 7 日後までの間 $\mathrm{CO}_{2}$ 濃度がほぼ 16 〜19\%で推移しており，H 4 フィルムは15１9\%で推 移していた。

\section{考察}

ブロッコリーの呼吸量, エチレン発生量は保存温度と 密接な関係にあり，低温ほど少なく，商品性が著しく低 
Table $7 \mathrm{CO}_{2}$ and $\mathrm{O}_{2}$ concentation in film bags in which broccoli 'Haitsu' was packaged

\begin{tabular}{|c|c|c|c|c|c|c|c|c|c|c|c|c|}
\hline \multirow{4}{*}{ film* } & \multicolumn{6}{|c|}{$5^{\circ} \mathrm{C}$ storage } & \multicolumn{6}{|c|}{$20^{\circ} \mathrm{C}$ storage } \\
\hline & \multicolumn{3}{|c|}{$\mathrm{CO}_{2} \%$} & \multicolumn{3}{|c|}{$\mathrm{O}_{2} \%$} & \multicolumn{3}{|c|}{$\mathrm{CO}_{2} \%$} & \multicolumn{3}{|c|}{$\mathrm{O}_{2} \%$} \\
\hline & \multicolumn{12}{|c|}{ storage period (days) } \\
\hline & 1 & 4 & 7 & 1 & 4 & 7 & 1 & 4 & 7 & 1 & 4 & 7 \\
\hline $\mathrm{L} 1$ & 1.9 & 0.7 & 0.8 & 18.9 & 17.4 & 17.7 & 2.5 & 1.9 & 1.3 & 16.8 & 13.3 & 12.2 \\
\hline $\mathrm{L} 2$ & 3.3 & 2.8 & 1.6 & 16.4 & 15.5 & 13.8 & 6.4 & 7.3 & 5.2 & 10.3 & 7.5 & 7.8 \\
\hline L 3 & 10.5 & 9.4 & 8.6 & 7.9 & 7.5 & 7.1 & 12.5 & 13.5 & 10.3 & 6.4 & 4.9 & 3.3 \\
\hline $\mathrm{L}_{4}$ & 13.3 & 13.5 & 12.8 & 5.6 & 4.4 & 2.3 & 18.3 & 18.8 & 15.7 & 2.5 & 2.3 & 1.4 \\
\hline H 1 & 0.4 & 0.2 & 0.4 & 20.3 & 20.4 & 20.5 & 0.7 & 0.5 & 0.4 & 20.0 & 20.3 & 20.1 \\
\hline H 2 & 1.3 & 0.9 & 1.0 & 18.7 & 17.5 & 18.2 & 3.0 & 3.8 & 1.6 & 16.5 & 12.4 & 14.3 \\
\hline H 3 & 6.7 & 4.2 & 4.6 & 12.5 & 10.6 & 9.5 & 8.9 & 9.4 & 6.9 & 7.5 & 5.9 & 4.8 \\
\hline $\mathrm{H} 4$ & 10.4 & 15.3 & 17.9 & 5.7 & 2.8 & 1.9 & 15.1 & 17.2 & 15.3 & 4.5 & 1.1 & 1.5 \\
\hline non & 0.0 & 0.0 & 0.0 & 20.5 & 20.8 & 20.7 & 0.0 & 0.0 & 0.0 & 20.3 & 20.7 & 20.7 \\
\hline
\end{tabular}

* same as in Table 1

$* 2 \sim * 4$; same as in Table 5

$* 5$ - ; sample rotted

下寸る花蕾の黄化が抑制されるので，高温時収穫のブロ ッコリーでは収穫直後の予冷および低温保存は鮮度保持 の観点から不可欠のものであると考えられた。

花蕾の生育ステージと呼吸量およびエチレン発生量の 関係では花蕾が軟らかくなった段階で増加し始めた。こ の点で寺井ら ${ }^{2)}$ はエチレンの増加が主に花蕾部によるも のと報告している。エチレンの急増は黄化等品質低下を 促進するので，収穫時の箱詰めでは花蕾が硬い段階で収 穫し，花蕾の生育ステージを揃えることが重要であると 考えられる。

供試品種間に呼吸量の差がみられ，早生品種の’ハイ ツ’ ‘グリンビューティ'は中晚生の‘唐嶺” “緑嶺’よりも呼 吸量が多い傾向にあった。しかしながら，その差は保存 温度や花蕾の生育ステージに比べれば小さいと考えられ た。

呼吸量は収穫 7 日後には収穫直後の $1 / 2$ 程度に減少し ていた。収穫後の呼吸量が減少傾向にあることから柑橘 類 ${ }^{9)}$ と同様に呼吸型は漸減型であると推察される。

$0{ }^{\circ} \mathrm{C}, \quad 5{ }^{\circ} \mathrm{C}$ の保存条件ではフィルムの種類および $\mathrm{O}_{2}$ 透過量の違いによる鮮度保持期間にほとんど差が見られ なかった。フィルム内に蓄積した $\mathrm{CO}_{2}$ 濃度はフィルムの 違いにより異なっていた。 KUBO ら ${ }^{10)}$ ，壇ら ${ }^{11)}$ は高 $\mathrm{O}_{2}$ 条 件下では， $\mathrm{CO}_{2}$ が増加しても呼吸抑制効果は少ないと報 告しているが, 本試験では $\mathrm{CO}_{2}$ の増加にともない, $\mathrm{O}_{2}$ 濃 度は低下していた。したがって， $\mathrm{O}_{2}$ 透過性の高いフィ ルムでは呼吸抑制効果があると推察されるが，低温条件 のため呼吸量そのものが少ないのと水分減少率が低いた めに，外観鮮度の差が小さくなったものと考えられる。 $10^{\circ} \mathrm{C}$ の保存条件では L $3, \mathrm{H} 4$ の $\mathrm{O}_{2}$ 透過量 $4000 \mathrm{~m} \ell /$ $\mathrm{m}^{2} \cdot \operatorname{day} \cdot \operatorname{atm}\left(15^{\circ} \mathrm{C}\right)$ 程度のフィルムの外観鮮度がや や優れており，異臬の発生も少なかった。 $20^{\circ} \mathrm{C}$ の保存 条件でも $\mathrm{O}_{2}$ 透過量 $4000 \mathrm{~m} \ell / \mathrm{m}^{2} \cdot \mathrm{day} \cdot \mathrm{atm}$ 程度のフィル ムの外観鮮度はやや優れていたが, 異臭が発生した。フ イルム内に $\mathrm{CO}_{2}$ が蓄積した包材ほど緑色が保持された。 この点に関して阿部ら ${ }^{12)}$ はブロッコリーの緑色保持には 高濃度 $\mathrm{CO}_{2}$ の影響が低濃度 $\mathrm{O}_{2}$ よりも大きいと報告してい る。さらに阿部ら ${ }^{12)}$, 別府13) らは異臭に含まれるエチル アルコールが黄化に関与する酵素に影響を及ぼし黄化を 抑制すると報告している。

夏季高温時の場合流通段階での品温変化の幅は大きく,

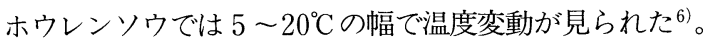
茨木ら ${ }^{5)}$ も輸送中にネギの品温変化が生じることを報告 している。したがって, 高温時流通では異臭の発生の可 能性が高いので, $\mathrm{O}_{2}$ 透過量 $7000 \sim 10000 \mathrm{~m} \ell / \mathrm{m}^{2} \cdot \mathrm{day} \cdot$ atm程度のフィルム使用が安全であり，品温が $20^{\circ} \mathrm{C}$ を越 之る場合には $\mathrm{O}_{2}$ 透過量 $10000 \mathrm{~m} \ell / \mathrm{m}^{2} \cdot \mathrm{day} \cdot \mathrm{atm}$ 以上の フィルムを使用する必要があるものと推察される。

素材がポリプロピレンによる微細孔フィルムは低密度 ポリエチレンフィルムに比べて $\mathrm{O}_{2}$ 透過量がほぼ同じ場 合, $\mathrm{CO}_{2}$ の蓄積量が多い傾向にあった。本試験ではその 原因は不明であり，今後詳細に検討する必要があるもの と思われた。

\section{要 約}

ブロッコリーの収穫後の呼吸量およびエチレン発生量 を測定するとともに， $\mathrm{O}_{2}$ 透過量の異なるフィルムを用 
いて各種フィルムの鮮度保持効果を検討した。

1. 呼吸量は保存温度が高いほど多く, 収穫 7 日後では 収穫直後の $1 / 2$ 以下に減少した。エチレン発生量は $10^{\circ} \mathrm{C}$ 以下は比較的少なく，150 $\mathrm{C}$ 以上で激増していた。

2. 花蕾の状況による呼吸量の差は小さいが花蕾が軟ら かくなった段階で呼吸量は多かった。エチレン発生量は 花蕾が少し軟らかくなった段階で増加し始め，花蕾が軟 らかい段階で急増した。

3. 呼吸量は品種間に差がみられ，早生品種は中晚生品 種に比べ，呼吸量が多い傾向にあった。

4. $0{ }^{\circ} \mathrm{C}$ と $5{ }^{\circ} \mathrm{C}$ 温度条件下ではフィルムの包材による

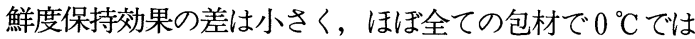
2 週間， 5 ㅇでは 1 週間高鮮度状態が保てた。

5.ほぼ全ての包材で $10^{\circ} \mathrm{C}$ の温度条件下で 4 日間高鮮 度状態を保て，比較的 $\mathrm{O}_{2}$ 透過量の少ない包材では $10^{\circ} \mathrm{C}$ で 7 日間， $20^{\circ} \mathrm{C}$ で 4 日間外観鮮度の高い状態に保てた。 しかしながら, $\mathrm{O}_{2}$ 透過量の少ない包材では異臭が感じ られた。

6. $10^{\circ} \mathrm{C}$ 以下の低温流通が確保できれば， $\mathrm{O}_{2}$ 透過量 $4000 \mathrm{~m} \ell / \mathrm{m}^{2} \cdot \mathrm{day} \cdot \mathrm{atm}\left(15^{\circ} \mathrm{C}\right)$ 程度のフィルムの鮮度 保持効果が高いが，流通途上で品温が $20^{\circ} \mathrm{C}$ を越える可 能性の場合には $\mathrm{O}_{2}$ 透過量 $10000 \mathrm{~m} \ell / \mathrm{m}^{2} \cdot \mathrm{day} \cdot \mathrm{atm}$ 以上 のフィルムを使用する方が実用的であると考えられた。

謝 辞 本研究は農林水産省地域重要新技術開発促進 事業「機能性フィルム等と温度管理を活用した野菜の高 鮮度保持流通技術の確立」で取り組んだ課題の一部であ り，取りまとめに当たってのご指導とフィルムの提供を 賜った農林水産省農研センター第 4 プロジェクトチーム の各位に厚く御礼申し上げます。

\section{文献}

1）永井耕介- 有方千裕 - 小河拓也 - 中川勝也：近畿中 国農研，89，49（1995）

2 ）寺井弘分 ·土田広信・水野雅史 ·日食低温誌，19, 194 (1993)

3）山下市二・小林恭一：日食低温誌，19，8 (1993)

4 ）緒方邦安・伊藤 卓 - 岩田 隆：日食工誌 21, 394 (1974)

5 ）茨城俊行 - 池田浩暢 - 打田 宏・太田英明：日食低 温誌, 21，69 (1995)

6 ）永井耕介 - 羽㴊維子- 小河拓也 - 中川勝也：日食保 科誌，23，136（1997）

7 ）㢣 一平・阿部一博・茶珍和雄：日食低温誌１6, 148 (1990)

8 ）太田英明 - 與座宏一 - 中谷明雄 - 椎名武夫 - 井尻 勉・石谷孝佑：日食低温誌，17，106（1991）

9 ）樽谷隆之・北河博敏：園芸食品の流通・貯蔵・加工 (養賢堂，東京), p.36 (1990)

10) Kubo, Y., InABA, A. and NAKAmurA, R. : J. Japan. Soc. Hort. Sci., 58, 731 (1990)

11）壇和 弘 - 永田雅靖 - 山下市二：日食低温誌, 21, 128 (1995)

12）阿部一博 - 㢣 一平 - 茶珍和雄 : 日食低温誌, 21, 208 209（1995）

13）別府道子・片平理子：日食低温誌，21，223 (1995)

(平成 9 年 6 月 18 日受理) 